\title{
The Role of Malaysian Online Media for Achieving the SDGs and the Malaysia's Development Agenda
}

\author{
Dr Nik Norma Nik Hasan \\ Deputy Dean (Academic) \\ School of Communication \\ Universiti Sains Malaysia \\ Penang, Malaysia \\ niknorma@usm.my
}

\begin{abstract}
In this presentation I argue that the media are important tools of national development. One way to propel the SDGs into the public sphere and planes of national discourse is through the media because of its ability to hold government accountable to the people. Subsequently, the role of the media in development will be: to serve as nation builders, partners with government, agents of empowerment as well as watchdogs and guardians of transparency. This study used the News Framing theory to examine how Malaysian online newspapers framed the Sustainable Development Goals (SDGs) which also aligns with the 11th Malaysia Plan (2016-2020). Previous research already shows that Malaysians exhibit an intensive online news consumption behavior. This suggests that the Malaysian online newspapers can assign importance to developmental issues and raise them to the planes of national discourse. The significant themes from the findings appeared in five broad themes: economy, education, environment, infrastructure and poverty. These themes intermingled with all the 17SDGs and 11MP. Salience was attributed to Malaysian development agendas through routinely used key words and phrases, news elements and news sources. This suggests that the sampled Malaysian online newspapers served a watchdog role.
\end{abstract}

Keywords: Sustainable development goals, $11^{\text {th }}$ Malaysia plan, online media, development journalism

\section{BACKGROUND}

The Sustainable Development Goals (SDGs) are a new universal set of development targets which replaced the Millennium Development Goals (MDGs), following its adoption by United Nations (UN) member countries, including Malaysia, on September 25, 2015. It targets to end poverty, protect the planet, and ensure prosperity for all as part of a new sustainable development agenda. Each goal has specific targets to be achieved over the next 15 years comprising 17 goals to transform the world by the year 2030 (UN Sustainable Development Goals, 2016). Experts argue that if the SDGs are ignored in the public sphere, then politicians won ${ }^{\text {eet }}$ necessarily feel they must be held accountable for them (Goldsmith, 2016). This paper argues too, that one way to propel the SDGs into the public sphere and planes of 
national discourse is through the media because of its ability to hold government accountable to the people. This role ascribed to the media supports the arguments of Goldsmith (2016) that transforming government policies into practical action is a way that civil society can hold government accountable to its promises to the people.

More so, the media is a vibrant component of the civil society and its main staple is news. In Malaysia, the audience of the media consumes news online (Ding, Koh, \& Surin, 2013). Their consumption behavior shows intensive use of online news sites (Freeman, 2013). In 2015, 71.1 percent of Malaysian individuals who are 15 years and above used the internet in mobility, at work places and commercial facilities (Department of Statistics Malaysia, 2016a). These internet users represent over 21 million people and translates into over two-thirds of the country"s estimated population, of over 31.7 million (Department of Statistics Malaysia, 2016b). These massive internet users are potential readers of news since the number of people reading news online in Malaysia is increasing (Ding et al., 2013). Furthermore, the scope of the SDGs is ambitious and hard to portray. Explaining 17 goals with 169 broad targets also means they cannot be pigeonholed into one category, while the news media is often organized by themes, such as science, health or security (Goldsmith, 2016).

This study argues that the media are important tools of national development (McDaniel, 1986), which can work with government to promote the larger good of social harmony and stability together with economic growth and development (Wong, 2004). Subsequently, the role of the media in development will be: to serve as nation builders, partners with government, agents of empowerment as well as watchdogs and guardians of transparency. In nation building, the news can maintain social stability, build social harmony, strengthen national economy and provide solutions. As partners, journalists can cater for overriding national interests of social, economic and political development priorities, thereby empowering ordinary people, to participate in public life and human development. Journalists also perform their watchdog roles by monitoring the performance of government and making it transparent to the public in a free environment to guarantee good governance and economic development (Xiaoge, 2009).

Therefore, it becomes imperative to explore how Malaysian online newspapers mainstream the SDGs into national consciousness by examining which Malaysian development agenda in line with the SDGs are used to transfer attributes of salience. How are such issues framed - what key words and phrases are routinely repeated? Who are the information sources? Which ideas (themes) are highlighted to reinforce facts or judgments? How are news elements (headline, lead, body text, photo caption) used to emphasize or exclude arguments on the SDGs that fit into the Malaysian development agenda in the news?

\section{SDGs AND MALAYSIA's DEVELOPMENT AGENDA}

The SDGs, as noted earlier, were adopted by UN member countries in 2015 to end poverty, protect the planet, and ensure prosperity for all as part of a new global sustainable development agenda with specific goals and targets for the next 15 years. The UN member countries target to use the 17 SDGs illustrated below to transform the world by the year 2030: 


\section{SUSTAINABLE DEVELOPMENT}
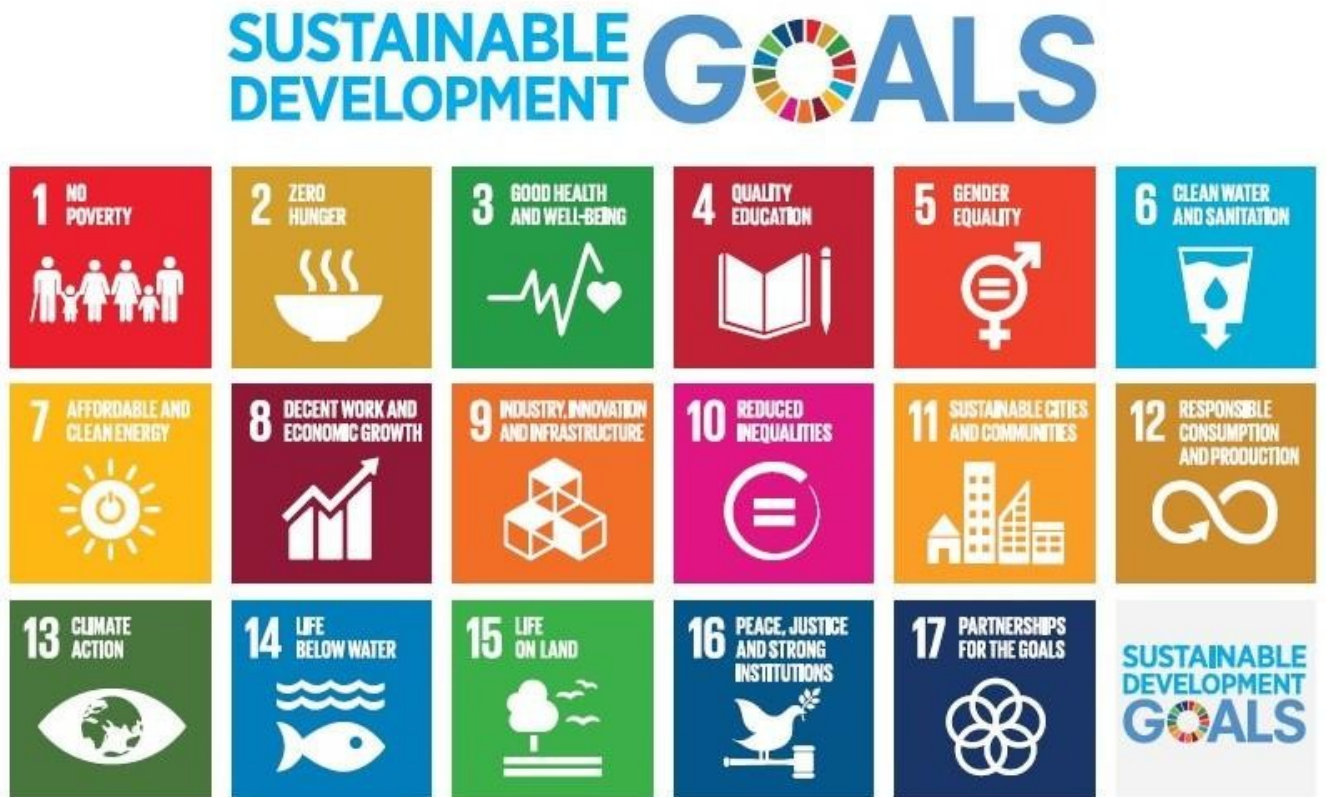

SUSTAINABLE DEVELOPMENT GEALS

Figure 1. UN"es Sustainable Development Goals

(Source: UN Sustainable Development Knowledge Platform (2016)).

In Malaysia, six strategic thrusts were outlined to attain the SDGs as contained in the 11th Malaysia Plan (2016-2020) to enhance inclusiveness towards an equitable society, improve wellbeing for all, accelerate human capital development for an advanced nation, pursue green growth for sustainability and resilience, strengthen infrastructure to support economic expansion and re-engineer economic growth for greater prosperity (Eleventh Malaysia Plan, 2015). Noteworthy, Malaysia has attained some of the SDGs like eradicating extreme poverty, according to UN and World Bank studies and the 11MP (Eleventh Malaysia Plan, 2015; Hanis, 2016). Poverty rate is 0.6 per cent, average household monthly income is RM6,141 (approximately US\$1,287@RM4.77/US\$1), family wellbeing index is 7.55 out of ten, 95.1 per cent of Malaysians have access to potable water, 97.6 per cent have access to electricity, approximately 76.1 per cent of households and 75.3 per cent of poor household own homes respectively, and national per capita income is US\$10,796. It is well on track to surpass the US\$15,000 threshold of a high-income economy by 2020 (Eleventh Malaysia Plan, 2015). These preceding development achievements fall in chronological order within SDG 1 (No poverty) and SDG 2 (Zero hunger), SDG3 (Good health and well-being), SDG 6 (Clean Water and Sanitation), SDG 7 (Affordable and Clean Energy), and SDG 10 (Reduced Inequalities).

Malaysia has equally transformed itself from a raw material producing economy to a diversified economy and a leading exporter of high-tech products. Malaysia is even categorized as a highly open, upper-middle income economy with an inclusive economic growth (Eleventh Malaysia Plan, 2015; World Bank, 2015). The transformation has however created development challenges of environmental sustainability (Climate Action - SDG 13). Climate action is becoming more urgent as the world suffers more and more from growing carbon footprint, global warming and disastrous climate changes globally (Hanis, 2016). Malaysiae's environmental challenges are also multifaceted - the country experienced its worst floods in 2014. They were blamed on deforestation and climate change, termed as the reason behind rising sea levels that are eroding the coast. The annual haze is blamed on forest fires, 
causing breathing problems that affect millions of people across the region (Rahman, 2016).

The above shows that environmental sustainability is a huge challenge with multidimensional consequences to Malaysiaees attainment of SDG13 (Climate Action). Climate Action as shown above has direct links to current realities in Malaysia - large scale agricultural investments in the country and Southeast Asia. Specifically, Malaysia has been strongly criticized for poor development planning, weak environmental regulation, and human rights violations on palm production and timber logging (Amanda, 2015). These earn huge foreign exchange for Malaysia but with heavy costs in terms of excessive health risks and environmental degradation and pollution. Hence, "the central challenge for Malaysia as it faces the SDG era will be to find a path to growth that does not sacrifice the health and welfare of individuals and the environment" (Amanda, 2015).

\section{THEORETICAL CONTEXT}

This study is situated within the news framing theory. "Media frames are persistent patterns of cognition, interpretation, and presentation, of selection, emphasis, and exclusion, by which symbol-handlers routinely organize discourse, whether verbal or visual" (Gitlin, 1980, p. 7). It is "the process by which a communication source constructs and defines a social or political issue for the audience" (Nelson, Oxley, \& Clawson, 1997, p. 221). Therefore, framing transfers the attributes of salience in news through the selection of restricted number of theatrically related attributes for inclusion in the media when an object or issue is discussed (Griffin, 2012). This means framing involves how an issue is thought about (Scheufele \& Tewksbury, 2007).

News angle is closely tied to framing since it is concerned with the importance assigned to attributes of an issue (Scheufele, 2000) and framing could be episodic or thematic. Episodic frame depicts public issues in terms of concrete instances or specific events. Thematic frames place public issues in some general or abstract context (Iyengar \& Simon, 1993). In addition, frames in news define problems by determining what a causal agent is doing with what costs and benefits; it diagnose causes by identifying the forces creating the problem; it makes moral judgments by evaluating (assessing) causal agents and their effects; it suggests remedies by offering and justifying treatments for the problems (Entman, 1993); and it predicts consequences that could arise from an issue or event (Chu \& Hamidah, 2010).

This study examined the attributes of salience and their manifestation in the framing of the SDGs, a recent strategic development agenda, vis-à-vis the Malaysian 11MP because news is information about recent events deemed to be interesting, important, or unusual enough to be newsworthy or fresh information about less recent events, that is gathered, verified, and structured based on journalistic norms. News reporting, is therefore, a process of selection. It allows only a tiny proportion of events happening in the world every day to become news. To help journalists decide which ones to select, journalists apply news judgments but such news values are relative because what is considered newsworthy differs over time, location, and between different media, with the perceived audience interests (Harcup, 2014). Several studies (Cook, 2005; Lawrence, 2000; Manning, 2001; Reich, 2009) suggest that news sources are invaluable in offering a way to verify accounts of events, add credibility 
to the news story, reduce uncertainty under deadline pressure, provide diverse viewpoints and protect against accusations of bias. Nelson et al. (1997) add that relying on certain sources heavily, narrows the range of frames and constrains public debate on the issue. Thus, coverage of issues can be selective and where all sources are not quoted, not all angles will be explored and not all relevant facts will be cited. Therefore, news sources are important in understanding the way news stories are presented (Tumber, 2002). It is also critical to apply journalistic strategic rituals to work with several news sources when constructing news reports, so that one party ${ }^{\text {ee }}$ s version of reality is balanced by competing accounts from other sources within the news to defend its objectivity (Tuchman, 1972 as cited in Manning, 2001).

\section{METHODOLOGY:}

\section{Data collection}

A census of English Language news articles on the SDGs in mainstream and alternative Malaysian online newspapers were analyzed (See Table 1). The mainstream newspapers included The Star Online, New Straits Times, Malay Mail Online and Borneo Post Online. Alternative newspapers comprised Malaysiakini and Free Malaysia Today. The news was searched over a period of three weeks from 1st to 31st March 2017 and retrieved from the websites of the online newspapers, the Bernama Library and Information Services (BLIS) and Google archives using the search phrases "sustainable development goal(s)", "SDG(s)" and "Malaysian newspaper(s)". The BLIS is a Malaysian digital archive of news and media resources. The articles found and retrieved from the search comprised publications from April 2013 to December 2016. These dates were not determined by the author but informed by the dates of publication on the articles retrieved from the search.

\section{Data Analysis}

The data was analyzed using thematic analysis to allow the researcher to identify, analyze, and report patterns (themes) within data and to organize and describe the data (Braun \& Clarke, 2006). The themes - which are similar codes aggregated together to form a major idea in the database (Cresswell, 2012) were sought using the research questions based on the components within the theoretical framework used for the study. Subsequently, the themes were categorized using selective coding. Daymon and Holloway (2002) explain that selective coding is to code for the main phenomenon. They argue that, like a thread, the category weaves through the others, integrating them and providing the storyline to uncover the essence of the study. This was used to integrate all the SDG elements. Selective coding was used since the SDGs was the main category and the aim was to uncover how Malaysian online newspapers mainstream the SDGs into national consciousness by examining which Malaysian development agenda in line with the SDGs are used to transfer attributes of salience. The units of analyses included all news elements found in the news on the SDGs - headline, news lead, body text, photo and photo caption.

Table 1: Summary of SDGs news in Malaysian online newspapers

\begin{tabular}{|c|c|c|c|}
\hline & & $\mathbf{N}$ & Total \\
\hline \multirow{2}{*}{$\begin{array}{l}\text { Content } \\
\text { category }\end{array}$} & Hard news & 12 & 19 \\
\hline & $\begin{array}{l}\text { Op-Ed (commentaries, views, letter-to-the- } \\
\text { editor) }\end{array}$ & 7 & \\
\hline \multirow{2}{*}{$\begin{array}{l}\text { Language of } \\
\text { communication }\end{array}$} & English & 16 & 19 \\
\hline & Bahasa Malaysia & 3 & \\
\hline Publication per & Mainstream & $N$ & \\
\hline
\end{tabular}




\begin{tabular}{|c|c|c|c|c|c|c|c|}
\hline \multirow{5}{*}{\multicolumn{2}{|c|}{$\begin{array}{l}\text { online } \\
\text { newspaper }\end{array}$}} & \multicolumn{2}{|c|}{ New Straits Times } & $\begin{array}{l}\mathrm{F} \\
\mathrm{T}\end{array}$ & $\begin{array}{l}\text { Free Malaysia } \\
\text { Today }\end{array}$ & 1 & 19 \\
\hline & & \multicolumn{2}{|c|}{ The Star Online } & 4 & Malaysiakini & 1 & \\
\hline & & \multicolumn{2}{|c|}{ Utusan Malaysia } & 3 & & & \\
\hline & & \multicolumn{2}{|c|}{ Malay Mail Online } & 2 & & & \\
\hline & & \multicolumn{2}{|c|}{ Borneo Post Online } & 1 & & & \\
\hline \multicolumn{2}{|c|}{ Year published } & \multicolumn{2}{|l|}{2016} & 14 & & & \\
\hline & & \multicolumn{2}{|l|}{2015} & 2 & & & \\
\hline & & \multicolumn{2}{|l|}{2014} & 1 & & & \\
\hline & & \multicolumn{2}{|l|}{2013} & 2 & & & \\
\hline \multicolumn{8}{|c|}{ Summary of news in English Language } \\
\hline \multirow{2}{*}{$\begin{array}{l}\text { Content } \\
\text { category }\end{array}$} & Borneo & Free & Malay & Malays & New & The & \\
\hline & $\begin{array}{l}\text { Post } \\
\text { Online }\end{array}$ & $\begin{array}{l}\text { Malaysi } \\
\text { a Today }\end{array}$ & $\begin{array}{l}\text { Mail } \\
\text { Online }\end{array}$ & akini & $\begin{array}{l}\text { Straits } \\
\text { Times }\end{array}$ & $\begin{array}{l}\text { Star } \\
\text { Online }\end{array}$ & \\
\hline $\begin{array}{l}\text { Hard } \\
\text { news }\end{array}$ & 1 & 0 & 2 & 0 & 1 & 3 & 7 \\
\hline \multirow[t]{2}{*}{ Op-ed } & 0 & 1 & 0 & 1 & 6 & 1 & 9 \\
\hline & 1 & 1 & 2 & 1 & 7 & 4 & 16 \\
\hline
\end{tabular}

\section{RESULT:}

\section{Themes and attributes of salience}

The framing of news on the SDGs in Malaysian online news can be categorised into five broad significant themes: economy, education, environment, infrastructure and poverty. However, these themes intersperse with all the 17SDGs of no poverty; zero hunger; good health and well-being; quality education; gender equality; clean water and sanitation; affordable and clean energy; and decent work and economic growth.

The Borneo Post Online highlighted decent work and economic growth; industry, innovation and infrastructure and partnership for the goals (SDGs 8, 9, and 17). The Malaysian development agenda in $11 \mathrm{MP}$ are not compartmentalized like the SDGs. However, the above SDGs are reflected in Malaysiaees development agenda of: strengthening infrastructure to support economic expansion [and education], inclusiveness towards equitable society, and re-engineering economic growth for greater prosperity. The Malay Mail Online highlighted no poverty; zero hunger; industry, innovation and infrastructure; reduced inequalities; climate action and partnerships for the goals (SDGs 1, 2, 9, 10, 13 and 17). The Malaysian development agenda which reflected the forgoing SDGs seeks to: accelerate human capital development for an advanced nation, re-engineer economic growth for greater prosperity, enhance inclusiveness towards equitable society and pursue green growth for sustainability and resilience. The Star Online highlighted no poverty, quality education, decent work and economic growth, industry, innovation and infrastructure, sustainable cities and communities, climate action, and partnerships for the goals (SDG, 1, 4, 8, 9, 11, 13 and 17). These are reflected in the Malaysian development agenda towards: re-engineering economic growth for greater prosperity, strengthening infrastructure to support economic expansion, pursuing green growth for sustainability and resilience, and inclusiveness towards equitable society. The New Straits Times highlighted: no poverty, quality education, decent work and economic growth, industry, innovation and infrastructure, reduced inequalities, sustainable cities and communities, responsible consumption and production, climate action, peace, justice and strong institutions, partnerships for the goals (SDGs 1, 4, 8, 9, 10, 11, 12, 13,16 and 17). 
The two alternative online newspapers highlighted all SDGs 1 to 17 while all mainstream online newspapers highlighted industry, innovation and infrastructure; and partnership for the goals (SDGs 9 and 17), reflected in the Malaysian development agenda of: strengthening infrastructure to support economic expansion, re-engineering economic growth for greater prosperity and inclusiveness towards equitable society. Thus, the frames in alternative online newspapers were broader. All the Malaysiaes six strategic agenda thrusts too outlined in the $11 \mathrm{MP}$ were attributed salience in the news articles on the SDGs in Malaysian online newspapers.

\section{Manifestation of Frames}

Key words and phrases, news sources, photos and photo captions were routinely used in the news on the SDGs in Malaysian online newspapers to thematically reinforce facts and judgments from the SDGs and Malaysian development agenda. Table 2 below collate words used repeatedly. The key words "achieve" and "achieving" were collectively used in both alternative and mainstream online newspapers to repeatedly reinforce facts and judgments. Other words used separately were a collection of verbs in the present, past, continuous and process forms such as: on track and right track, committed and commitment, implementing and implementation, can lead and on course, and supporting. These reinforced that the development agenda set by Malaysia is in progress, yielding results, on the right path towards success and therefore, Malaysia, is in the fore front of nations that will achieve the SDGs and its national development agenda by the deadline set for the goals.

Table 2. Repeatedly used words

\begin{tabular}{|c|c|c|c|c|}
\hline \multicolumn{4}{|c|}{ Mainstream } & \multirow{2}{*}{$\begin{array}{l}\text { Alternative } \\
\text { Malaysiakini and } \\
\text { Free Malaysia Today }\end{array}$} \\
\hline $\begin{array}{l}\text { Borneo } \\
\text { Post } \\
\text { Online }\end{array}$ & $\begin{array}{l}\text { Malay Mail } \\
\text { Online }\end{array}$ & The Star Online & $\begin{array}{l}\text { New Straits } \\
\text { Times }\end{array}$ & \\
\hline $\begin{array}{l}\text { achieve, } \\
\text { achieving } \\
\text { on track }\end{array}$ & $\begin{array}{l}\text { achieve } \\
\text { committed } \\
\text { implementing } \\
\text { right track } \\
\text { supporting }\end{array}$ & $\begin{array}{l}\text { can lead } \\
\text { commitment, } \\
\text { committed } \\
\text { heading in the } \\
\text { right direction } \\
\text { implementing, } \\
\text { implementation } \\
\text { on course } \\
\text { supporting }\end{array}$ & $\begin{array}{l}\text { achieving } \\
\text { committed, } \\
\text { commitment } \\
\text { on track }\end{array}$ & $\begin{array}{l}\text { achieve, achieving } \\
\text { can lead } \\
\text { could be the first } \\
\text { implement, } \\
\text { implementing, } \\
\text { implementation }\end{array}$ \\
\hline
\end{tabular}

The ideas in which the arguments manifested were not diverse because they were drawn from few news sources, which were restricted to only topmost Malaysian political leaders, one international Non-Governmental Organization (the UN), and seven development experts. Predominantly, news articles used only one news source, except in two articles, which used two news sources. The top Malaysian political leaders who were quoted included the Prime Minister, his Deputy and the Deputy Transport Minister. Development experts were the most routinely used news sources. They were used nine times, all, in the opinion articles. Malaysian top political leaders were the second most routinely used news sources - they were used six times. The international NGO was used as a news source only once while major mainstream newspapers - New Straits Times and The Star Online routinely relied on development experts as news sources. New Straits Times used development expert as news sources five times while The Star Online used them twice. 
The political class highlighted that Malaysia has frameworks and is focused towards attaining the SDGs. It also reiterated its commitment, not just to implement the policies that will lead to the achievement of the goals, but the vision to make Malaysia the first nation to attain its development goals. Meanwhile, development experts and the international NGO appraised Malaysia ${ }^{\text {ee }}$ development agenda and development indices to identify gaps and proffer solutions.

Additionally, ideas in headlines, leads and body text, reinforced facts in the news of both alternative and mainstream online newspapers. These highlighted positive indices from assessment of the efforts of Malaysia towards attaining the SDGs. Table 3 below summarizes some examples of ideas used in headlines and news leads:

Table 3. Examples of positive ideas in headlines and leads

\begin{tabular}{|c|c|c|c|c|}
\hline $\begin{array}{l}\text { Date } \\
\text { published }\end{array}$ & $\begin{array}{l}\text { Newspaper } \\
\text { title }\end{array}$ & $\begin{array}{l}\text { News } \\
\text { element }\end{array}$ & $\begin{array}{l}\text { Idea } \\
\text { highlighted }\end{array}$ & $\begin{array}{l}\text { Typology of } \\
\text { newspaper }\end{array}$ \\
\hline \multirow[t]{2}{*}{ Oct. 25,2016} & $\begin{array}{l}\text { Borneo Post } \\
\text { Online }\end{array}$ & Headline & $\begin{array}{l}\text { Malaysia on track to achieve } \mathrm{UN}^{\text {ee }} \mathrm{s} \\
\text { SDGs by } 2030\end{array}$ & Mainstream \\
\hline & & Lead & $\begin{array}{l}\text { Malaysia is on track of achieving } \\
\text { the UN SDGs by 2030, according } \\
\text { to UN Resident Coordinator for } \\
\text { Malaysia... }\end{array}$ & \\
\hline \multirow{3}{*}{$\begin{array}{l}\text { Dec. } 16,2016 \\
\text { Dec. } 14,2016\end{array}$} & Free & Headline & $\mathrm{M}^{\text {ee }}$ sia can lead in implementing & Alternative \\
\hline & $\begin{array}{l}\text { Malaysia } \\
\text { Today } \\
\text { Malaysiakini }\end{array}$ & & Sustainable Development Goals & \\
\hline & & Lead & $\begin{array}{l}\text { Malaysia and Malaysians can be } \\
\text { proud and hopeful that we could be } \\
\text { the first country to fully implement } \\
\text { the UN inspired SDGs... }\end{array}$ & \\
\hline \multirow[t]{2}{*}{ Dec. 9, 2016} & $\begin{array}{l}\text { Malay Mail } \\
\text { Online }\end{array}$ & Headline & $\begin{array}{l}\text { Najib says Malaysia on the right } \\
\text { track in sustainable development }\end{array}$ & Mainstream \\
\hline & & Lead & $\begin{array}{l}\text { Malaysia has taken important steps } \\
\text { to develop the global expertise } \\
\text { needed to move it forward in } \\
\text { sustainable development, said } \\
\text { Prime Minister }\end{array}$ & \\
\hline Nov. 28, 2016 & $\begin{array}{l}\text { New Straits } \\
\text { Times }\end{array}$ & Headline & $\begin{array}{l}\text { Malaysia on track to achieving } \\
\text { global sustainable development } \\
\text { goals agenda }\end{array}$ & \\
\hline \multirow[t]{2}{*}{ Dec. 9,2016} & $\begin{array}{l}\text { The Star } \\
\text { Online }\end{array}$ & Headline & $\begin{array}{l}\text { Najib: Malaysia on course with } \\
\text { Sustainable development agenda }\end{array}$ & \\
\hline & & Lead & $\begin{array}{l}\text { Malaysia is heading in the right } \\
\text { direction in achieving its } \\
\text { sustainable development agenda... } \\
\quad \ldots \text { we have taken important } \\
\text { steps in the right direction to } \\
\text { develop the global expertise } \\
\text { needed to move Malaysia and Asia } \\
\text { forward in sustainable } \\
\text { development... }\end{array}$ & \\
\hline
\end{tabular}

It was also observed that while framing Malaysia as a country which is sufficiently prepared to achieve the SDGs on target, news elements like photo and photo caption complemented other news elements like headline, lead and body text. The photos used 
include photos of topmost Malaysian politicians like the Prime Minister and his Deputy, development expert writers of opinion-editorials.

There were also photos and photo captions of infrastructures but these were inconsistent with other news elements like headline, lead and body text. Notably, news elements are used routinely to complement news angles. However, this norm was violated in the news on the SDGs in Malaysian online newspapers. For example, in Figure 2 below, the photo and photo caption highlighted contrasting information with the news headline, which stated that "Malaysia is on track to achieving the global sustainable development goals (SDGs) agenda, particularly in the transport sector...", (New Straits Times, November 28, 2016). Instead, a photo of one of the nation "s commercial capital (Kuala Lumpur) skyline dotting the famous picturesque Petronas twin towers and skyscrapers surrounding the Kuala Lumpur Convention Centre (KLCC) was used. The photo in Figure 2 could have been appropriate if the news angle highlighted Sustainable cities and communities (SDG 11) and/or Climate action (SDG 13) due to the sky-scrappers and other buildings and the hazy horizon. An appropriate complementary photo could be one which draws from the key idea highlighted in the news angle and most probably, from Malaysia ${ }^{\text {ee }}$ thriving air, rail, road, or water transport sectors. Interestingly, the transportation sector intersperses between several SDGs including: decent work and economic growth (SDG 8), Industry, innovation and infrastructure (SDG 9), Reduced inequalities (SDG 10), Sustainable cities and communities (SDG 11) and Climate action (SDG 13).

News headline: Malaysia on track to achieving global sustainable development goals agenda

News lead: Malaysia is on track to achieving the global sustainable development goals (SDG) agenda, particularly in the transport sector, based on the country ${ }^{\text {ee }} \mathrm{s}$ current development strategies and goals...

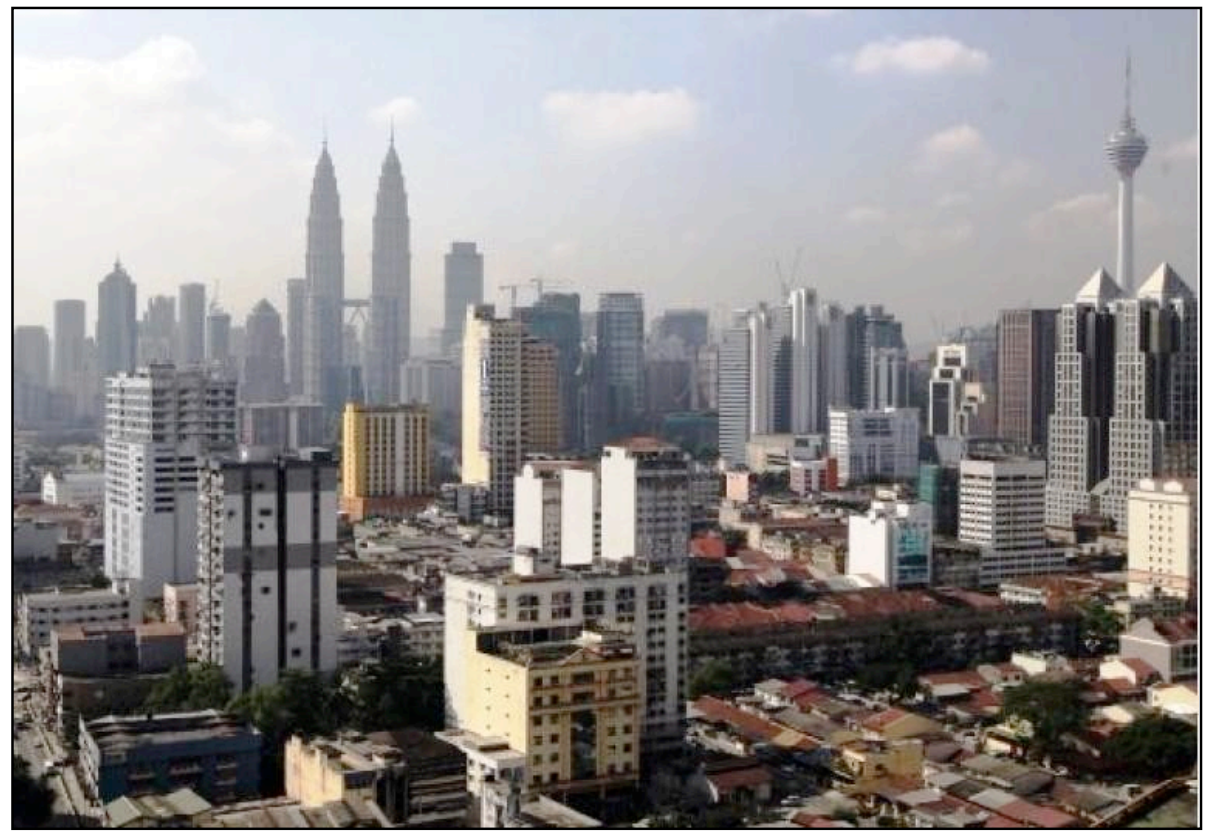

Figure 2. Malaysia is on track to achieving the global sustainable development goals (SDGs) agenda, particularly in the transport sector, based on the country ${ }^{\text {ee }}$ current development strategies and goals (New Straits Times, November 28, 2016) 
In addition, the themes in the news articles reinforced facts and judgments from: assessment, challenges and solutions. Assessment evaluates the successes and failures achieved or expected by Malaysia towards realizing its development agenda in relation to the SDGs. The challenges define the problems by identifying factors or issues that can counteract the attainment of the SDGs. Solutions suggest remedies, strategies and structures for attaining the SDGs. The themes were reinforced with facts and judgments through the assessment of Malaysia's current development achievements and vision. The assessments were predominantly positive with a few negative outlooks. The positive arguments reinforced that Malaysia is "on track" and "heading in the right direction" to achieve the SDGs and invariably, its development agenda based on track record and achievements of some of the SDGs, the exceptional and comprehensive evaluation of its development challenges, its strategic plans and implementation roadmap and existing infrastructure to facilitate and fast track the attainment of its development goals.

Positive development indices from the assessments were highlighted by all news sources and by mainstream and alternative online newspapers. The sources reinforced their arguments and pronounced that Malaysia is on track to achieve the SDGs and its development agenda because: Malaysia has practically erased poverty, does not suffer from hunger; there is great improvements in gender equality; and there is an innovative transformation of Malaysiae s economy, industries and infrastructure as cited below:

\footnotetext{
Industry innovation and infrastructure has been quite impressive in Malaysia. From agriculture, we moved successfully into manufacturing and industrial innovation..., a development expert said (Free Malaysia Today, December 15, 2016).

...the Government had also been making headway into transforming the nation ${ }^{\text {ee }}$ s economy from reliance on mostly agriculture to diversification under the "industry innovation and infrastructure" aspect of the SDGs...," a development expert said (The Star Online, December 15, 2016).
}

Challenges to the attainment of the SDGs and Malaysia ${ }^{\text {ee }}$ s development agenda were highlighted by signposting negative development. These appeared in only alternative online newspapers. The mainstream online newspapers did not highlight negative indices as challenges. The challenges to Malaysiaees attainment of the SDGs and its development plan highlighted by alternative online newspapers included: decline in general quality of education, poor well-being and dietary knowledge, increasing deterioration in health resulting in life-threatening ailments, lack of potable water and affordable and clean energy, and the endangerment of Malaysiae s flora and fauna as cited below:

Quality education is perceived to have declined generally...More and more Malaysians do not have a good sense of wellbeing, due... to low standards of living, inflation, corruption, insecurity and declining human rights. [There is]

...considerable malnutrition due [to] poor dietary knowledge and low incomes that are just above the poverty line... [and] growing signs of deterioration as in the case of diabetes and diseases, such as TB and malaria...tap water is often dirty and we need to boil and filter the tap water before we drink it. But many in rural areas do not even have access to tap water. Affordable and clean energy is somewhat lacking. Energy costs have been rising and should be much cleaner to protect our health through a cleaner environment. Worse still many areas in the country do not have access to energy. 
We [Malaysia] have plenty of sunlight but ironically use little solar energy. We have not done enough to protect our wildlife... and many other dying species of flora and fauna... Reduced inequalities is a growing and major problem in our country... said a development expert (Free Malaysia Today, December 15, 2016; Malaysiakini, December 14, 2016).

Solutions were highlighted for the attainment of the SDGs in Malaysia in both mainstream and alternative online newspapers. These solutions targeted multiple sectors and agendas of the SDGs, including: no poverty (SDG 1), quality education (SDG 4), industry, innovation and infrastructure (SDG 9), reduced inequalities (SDG 10), sustainable cities and communities (SDG 11), responsible consumption and production (SDG 12), climate action (SDG 13), life below water (SDG 14), and promoting partnerships for the goals (SDG 17). The solutions detailed plans, policies under implementation and those already implemented in the above areas thus:

...low poverty does not mean that we in Malaysia are satisfied with our low incomes Hence, we have to raise our incomes well above the poverty line, to feel satisfied and happier...

...but to move forward more deliberately and not to be caught in the middleincome trap, we have to innovate even more... Our marine life must be protected and preserved as part of our food supplies and eco system. We have to strengthen our marine enforcement authorities and clean up our dirty rivers and lakes more earnestly, said a development expert (Free Malaysia Today, December 15, 2016; Malaysiakini, December 14, 2016).

\begin{abstract}
...high- tech "smart villages" which are currently under construction... provides affordable homes, high- tech educational, training and recreational facilities, with an integrated, sustainable farm system providing villagers with food and employment lifting incomes for scores of rural families while promoting environmental sustainability. The low- carbon cities framework... offers a guide to planning low- carbon cities and their management, including an assessment system...

...MYBiomass, is a special- purpose vehicle dedicated to turning waste into wealth through pioneering technology for converting oil palm industry"s waste biomass and refining it into high value green chemicals..., said a development expert (New Straits Times, March 3, 2015).
\end{abstract}

\title{
DISCUSSION
}

The routinely used news sources were development experts and multiple sources were scarcely used, even in hard news. This may have resulted because nine out of the news sample were op-eds or because the journalists and the editorial team have little access to other sources and chose to publish head-on opinion-editorials since these were usually published unedited. Already, Goldsmith (2016) explained that the scope of the SDGs is ambitious and hard to portray and findings from this study reveal that Malaysian top political leaders were the second most routinely used news sources. Again, Goldsmith (2016) explains that politicians should be held accountable for the attainment of the SDGs and this paper argues further that since policy and implementation decisions are the prerogative of top political leaders, they became the second most relied-upon news sources since the primary function of the news media in Malaysia is to help the government impart information and disseminate its policies for the betterment of the population. Therefore, Malaysian online newspapers performed their social responsibility role as subsets of the Malaysian media by highlighting all the SDGs and 11MP thematic clusters in their coverage. This means the online newspapers, as core elements of the civil society conveyed development agenda which the political class considered fundamental for Malaysia to attain the 
SDGs agenda by 2030 .

Nonetheless, this paper argues that by not citing multiple sources, the online newspapers have negated a very important news routine - fact checking from multiple news sources since several studies (Cook, 2005; Lawrence, 2000; Manning, 2001; Reich, 2009) affirmed that citing multiple news sources is important to verify accounts of events, add credibility to the news story, provide diverse viewpoints and protect against accusations of bias.

Additionally, alternative and mainstream online newspapers, published positive development indices from assessment which were highlighted by all news sources. However, only alternative online newspapers highlighted negative indices as challenges even though both alternative online newspapers (Free Malaysia Today, Malaysiakini) and mainstream online newspaper (The Star Online) received the op-ed in which both positive and negative Malaysian development indices were highlighted by the authors. Meanwhile, unlike the alternative online newspapers, which published the articles in full as opinions, The Star Online chose to write a hard news from the opinion, to frame the news positively and exclude negative development indices. Interestingly, key and influential mainstream online newspapers like the New Straits Times, The Star Online and the Malay Mail Online, did not highlight challenges of attaining the SDGs and Malaysia"es development agenda. Interestingly, The Star Online chose to write two hard news from the same op-ed which highlighted both positive and negative indices, and was written by a development expert and published in full in the two alternative online newspapers that highlighted negative indices from assessment of development in Malaysia. It however, excluded the challenges mentioned by the development expert.

Ideas in both alternative and mainstream online newspapers highlighted positive indices in headlines and leads to reinforce facts. Notably, headlines and leads are the most visible news elements in which attributes of salience are used to attract a reader. Therefore, if an idea is highlighted in the headline, it is most significantly visible, next to the idea highlighted in the lead and then in the body text and other elements like photo caption. Meanwhile, the routine in news reporting is for consistency to exist between the ideas in the news elements, or for one idea to be used to complement another. However, if inconsistent or contrasting ideas are highlighted across news elements, this raises questions on the editorial and news judgments of gatekeepers in news reporting. Therefore, signposting positive indices in the headlines and news lead is consistent with the notion of framing, since it is concerned with the importance assigned to attributes of an issue (Scheufele, 2000) and used to transfer attributes of salience in news on the media agenda when an object or issue is discussed (Griffin, 2012).

It is worthy to note that the intersperse emergence of five broad significant themes (i.e. infrastructure, economy, education, environment and poverty) across all 17SDGs and $11 \mathrm{MP}$ is a manifestation of the complex and interrelated nature of development issues and agenda. The themes in the 11MP seek to: enhance inclusiveness towards equitable society, improve wellbeing for all, accelerate human capital development for an advanced nation, pursue green growth for sustainability and resilience, strengthen infrastructure to support economic expansion, and re-engineer economic growth for greater prosperity. Therefore, in line with earlier arguments on the multi- 
dimensional perspective of the role of journalism in development, this paper argues from some of its findings and as theorized by Xiaoge (2009), that both Malaysian alternative and mainstream online newspapers served as partners with government, by catering for overriding national interests of social, economic and political development priorities. However, though both mainstream and alternative online newspapers served as watchdogs in monitoring performance of government on the SDGs and Malaysiaees development, only alternative online newspapers fully critiqued the development indices highlighting Malaysia"e development challenges.

Additionally, frames in news elements poorly complemented news angles despite common knowledge that the routine in news reporting is that news elements are used to guarantee consistency and complement ideas. This raises questions on the editorial and news judgments and competences of the gatekeepers in the news reporting process.

\section{BIBLIOGRAPHY}

Amanda, Y. (2015, October 7). Malaysia: Facing the challenges of sustainable development. Retrieved January 9, 2017, from

http://asiafoundation.org/2015/10/07/malaysia-facing-the-challenges-ofsustainable-development/

Bier, L. M., Park, S., \& Palenchar, M. J. (2017). Framing the flight MH370 mystery: A content analysis of Malaysian, Chinese, and U.S. media. International Communication Gazette, 1748048517707440. doi: 10.1177/1748048517707440

Borneo Post Online (2016, October 25). Malaysia on track to achieve United Nation "s Sustainable Development Goals by 2030. Retrieved from http://www.theborneopost.com

Braun, V., \& Clarke, V. (2006). Using thematic analysis in psychology. Qualitative Research in Psychology, 3(2), 77-101. http://dx.doi.org/10.1191/1478088706qp063oa

Chu, V. S. L., \& Hamidah, A. H. (2010). Media framing of waste issues in selected Malaysian newspapers. Journal of Human Capital Development, 3(1), 41-54. http://myais.fsktm.um.edu.my/11350/

Cook, T. E. (2005). Governing with the news: The news media as a political institution. Chicago: University of Chicago Press.

Cresswell, J. W. (2012). Educational research: Planning, conducting, and evaluating quantitative and qualitative research. Boston: Pearson.

Daymon, C. \& Holloway, I. (2002). Qualitative research methods in public relations and marketing communications. London: Routledge.

Department of Statistics Malaysia. (2016a, July 29). ICT use and access by individuals and households survey report, Malaysia, 2015. Retrieved January 9, 2017 from https://www.dosm.gov.my/v1/index.php? $\mathrm{r}=$ column/cthemeByCat\&cat=395\&bul_i $\mathrm{d}=\mathrm{Q} 313 \mathrm{WXJFbG1PNjRwcHZQTV1SR1UrQT09 \& menu \_ id=amVoWU54UT10a21}$ NWmdhMjFMMWcyZz09\#

Department of Statistics Malaysia. (2016b, September 22). Selected demographic estimates Malaysia 2016. Retrieved January 9, 2017, from https://www.dosm.gov.my/v1/index.php? $\mathrm{r}=$ column/cthemeByCat\&cat=397\&bul_i $\mathrm{d}=$ WVVQUnYrZkRwK1k1QXZMbEpuV1hNUT09\&menu_id=L0pheU43NWJW RWVSZklWdzQ4TlhUUT09 
Ding, J.-A., Koh, L. C., \& Surin, J. A. (2013). Mapping Digital Media: Malaysia. https://www.opensocietyfoundations.org/sites/default/files/mapping-digital-mediamalaysia-20130617.pdf

Eleventh Malaysia Plan. (2015). Eleventh Malaysia Plan 2016-2020: Anchoring growth on people. Retrieved from http://rmk11.epu.gov.my/index.php/en/

Entman, R. M. (1993). Framing: Toward clarification of a fractured paradigm. Journal of Communication, 43(4), 51-58. doi: 10.1111/j.1460-2466.1993.tb01304.x

Freeman, K. S. (2013). News consumption behavior of young adults in Malaysia. International Journal of Social Science and Humanity, 3(2), 121. doi:10.7763/IJSSH.2013.V3.209

Gitlin, T. (1980). The whole world is watching: Mass media in the making and unmaking of the new left. Berkeley: University of California Press.

Goldsmith, B. (2016, February 17). Why selling the SDGs isn't as easy as ABC, Opinion, Reuters. Retrieved from http://news.trust.org/item/20160217101218$4 \mathrm{t} 8 \mathrm{hs} /$

Griffin, E. (2012). A first look at communication theory. New York: McGraw Hill.

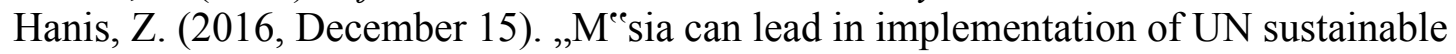
development goalse. The Star Online.

http://www.thestar.com.my/news/nation/2016/12/15/msia-can-lead-inimplementation-of-un-sustainable-development-goals/

Harcup, T. (2014). A Dictionary of Journalism. Oxford: Oxford University Press. Iyengar, S., \& Simon, A. (1993). News Coverage of the Gulf Crisis and Public Opinion. Communication Research, 20(3), 365-383. doi: doi:10.1177/009365093020003002

Joseph, K. J. (2016, December 9). Najib: Malaysia on course with sustainable development agenda, Hard news, The Star Online. Retrieved from http://www.thestar.com.my/news/nation/2016/12/09/najib-malaysia-on-coursewith-sustainable-development-agenda/

Kaos Jr, J. (2016, December 10). Najib launches Jeffrey Sachs Centre on Sustainable Development. The Star Online. Retrieved from http://www.thestar.com.my

Lawrence, R. G. (2000). The politics of force: Media and the construction of police brutality. Berkeley: University of California Press.

Mahadi, A. (2015, March 3). Sustainable development goals. New Straits Times. Retrieved from http://blis.bernama.com/getArticle.do? $\mathrm{id}=19604 \& \mathrm{tid}=135 \& \mathrm{cid}=3$

Malay Mail Online (2016, December 9). Najib says Malaysia on the right track in sustainable development. Retrieved from http://www.themalaymailonline.com

Manning, P. (2001). News and news sources: A critical introduction. London: Sage.

Manzo, K., \& Padfield, R. (2016). Palm oil not polar bears: climate change and development in Malaysian media. Transactions of the Institute of British Geographers, 41(4), 460-476. doi: 10.1111/tran.12129

McDaniel, D. (1986). Development news in two Asian nations. Journalism and Mass Communication Quarterly, 63(1), 167. http://search.proquest.com/openview/1ff5a2ce04f58f1 1c2b61f72504f2039/1?pqorigsite $=$ gscholar

Navaratnam, R. (2016, December 14). M“esia can lead in implementing Sustainable Development Goals. Malaysiakini. Retrieved from https://www.malaysiakini.com 
Navaratnam, R. (2016, December 15). M"sia can lead in implementing Sustainable Development Goals. Free Malaysia Today. Retrieved from http://www.freemalaysiatoday.com

Nelson, T. E., Oxley, Z. M., \& Clawson, R. A. (1997). Toward a psychology of framing effects. Political Behaviour, 19(3), 221-246. doi: 10.1023/a:1024834831093

New Straits Times (2016, November 28). Malaysia on track to achieving global sustainable development goals agenda. Retrieved from https://www.nst.com.my

Nik, N. N. H. (2016). Environmental rhetoric of haze risk. Paper presented at the International Conference of Communication, Industry and Community 2016, Bali, 3-4 March.

https://www.researchgate.net/profile/Sinta_Paramita2/publication/303274823_CO MMUNICATION_POLITICAL_YOUTH_CASE_STUDY_TEMAN_AHOK/link s/573ab5ee08ae9f741b2cb7cd.pdf $\#$ page $=199$

Parker, M. (2016, October 20). Huge challenges of urban housing. New Straits Times. Retrieved from https://www.nst.com.my

Rahman, S. (2016, April 24). Climate change: Malaysia takes lead in cutting carbon. Aljazeera. Retrieved January 14, 2017, from http://www.aljazeera.com/news/2016/04/malaysia-lead-cutting-carbon160423212712304.html

Reich, Z. (2009). Sourcing the news: Key issues in journalism. Cresskill, NJ: Hampton Press.

Scheufele, D. A. (2000). Agenda-Setting, Priming, and Framing Revisited: Another Look at Cognitive Effects of Political Communication. Mass Communication and Society, 3(2-3), 297-316. doi: 10.1207/S15327825MCS0323_07

Scheufele, D. A., \& Tewksbury, D. (2007). Framing, Agenda Setting, and Priming: The Evolution of Three Media Effects Models. Journal of Communication, 57(1), 9-20. doi: 10.1111/j.0021-9916.2007.00326.x

Tan, Y. L. (2004). Framing of Bali blast tragedy: An analysis of bulletin Utama News, TV3. (Master of Science), School of Communication, Universiti Sains Malaysia.

Teoh, Y. C., Yang, L. F., \& David, H. J. N. (2016). Framing diplomatic relations: A comparative analysis of Malaysian and Chinese newspapers coverage of Najib"s visit to China. SEARCH (The Journal of the South East Asia Research centre for Communication and Humanities), 8(2), 34-47.

http://search.taylors.edu.my/final_pdf/journals/Vol8_Issue2/Vol8_2_Sept16_5_J3. pdf

The Star Online. (2016, October 12). WHO lauds Malaysia"es dengue fight, The Star Online. Retrieved from http://www.thestar.com.my/news/nation/2016/10/12/wholauds-malaysias-dengue-fight-subra-says-more-needs-to-be-done-as-disease-isstill-a-threat/

Tiung, L. K., \& Hasim, M. S. (2009). Media framing of a political personality: A case study of a Malaysian politician. European Journal of Social Sciences, 9(3), 408424.

Tumber, H. (2002). Sources, the media and the reporting of conflict. In E. Gilboa (Ed.), Media and conflict: Framing issue, making policies, shaping opinions (pp. 135-153). Ardsley, NY: Transnational Publishers.

UN Sustainable Development Goals. (2016). Sustainable development goals: 17 goals to transform our world. http://www.un.org/sustainabledevelopment/sustainabledevelopment-goals/ 
UN Sustainable Development Knowledge Platform. (2016). Sustainable Development Goals. UN Sustainable Development Homepage. Retrieved January 8, 2017, from https://sustainabledevelopment.un.org/sdgs

Wong, K. (2004). Asian-Based Development Journalism and Political Elections. Gazette (Leiden, Netherlands), 66(1), 25-40. doi: doi:10.1177/0016549204039940

World Bank. (2015, October). Overview. Retrieved January 6, 2016, from http://www.worldbank.org/en/country/malaysia/overview

Xiaoge, X. (2009). Development journalism. In K. Wahl-Jorgensen \& T. Hanitzsch (Eds.), The Handbook of Journalism Studies (pp.357-370). New York: Routledge.

Yang, L. F., \& Leong, W. K. (2017). Framing the cow-head protest: A comparative analysis of The Star and Malaysiakini. SEARCH (The Journal of the South East Asia Research centre for Communication and Humanities), 9(1), 71-96. http://search.taylors.edu.my/final_pdf/journals/Vol9_Issue1/Vol9_1_Mar17_5_J4. pdf

Yang, L. F., \& Md. Sidin, A. I. (2016). Framing religious disputes: A comparative analysis of the Lina Joy controversy reported by Malaysian newspapers. SEARCH (The Journal of the South East Asia Research centre for Communication and Humanities), 3(2), 21-37. http://search.taylors.edu.my/final_pdf/journals/Vol3_Issue2/Vol3_2_Sept11_3_J2. pdf

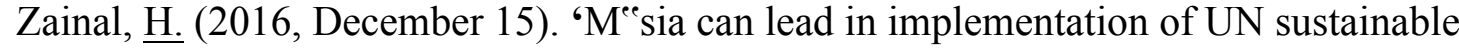
development goals ${ }^{\text {ee }}$. The Star Online. Retrieved from http://www.thestar.com.my 